$\begin{array}{cl}\begin{array}{c}\text { Revue } \\ \text { de Ihistoire } \\ \text { des religions }\end{array} & \text { Revue de l'histoire des religions } \\ & 2 \text { | } 2014 \\ & \text { Langue et autorité théologique à la fin du Moyen Âge }\end{array}$

\title{
Popular Authority in Conciliar and Canonistic Thought: the Case of Elections
}

Autorité populaire dans la pensée conciliaire et canonistique : le cas des élections

\section{Alexander Russell}

\section{(2) OpenEdition}

1 Journals

Electronic version

URL: http://journals.openedition.org/rhr/8254

DOI: $10.4000 /$ rhr.8254

ISSN: $2105-2573$

Publisher

Armand Colin

Printed version

Date of publication: 1 June 2014

Number of pages: $313-340$

ISBN: 978-2-200-92911-4

ISSN: 0035-1423

Electronic reference

Alexander Russell, "Popular Authority in Conciliar and Canonistic Thought: the Case of Elections », Revue de I'histoire des religions [Online], 2 | 2014, Online since 01 June 2017, connection on 30 April 2019. URL : http://journals.openedition.org/rhr/8254 ; DOI : 10.4000/rhr.8254 


\section{ALEXANDER RUSSELL \\ Pontifical Institute of Mediaeval Studies, Toronto \\ Centre for the Study of the Renaissance, University of Warwick \\ Popular Authority in Conciliar and Canonistic Thought: the Case of Elections}

This paper assesses the place of laypeople in the thought of $15^{\text {th }}$-century conciliarists. The dangers associated with heresy inclined the conciliarists towards a restrictive view of lay participation in doctrinal debates and ecclesiastical government. Yet, in legal commentaries regarding canonical elections, conciliarists like Francesco Zabarella and Niccolò Tudeschi admitted that popular participation in canonical elections was to be tolerated under certain conditions. This paper argues that the intellectual method of the canonists as well as certain practical considerations account for their open-mindedness about lay participation in canonical elections.

\section{Autorité populaire dans la pensée conciliaire et canonistique : le cas des élections}

Cet article évalue la place des lä̈cs dans la pensée des conciliaristes du $X V^{e}$ siècle. Dans un premier temps, les dangers associés à l'hérésie ont mené les conciliaristes à adopter une conception restrictive de la participation laïque dans les débats doctrinaux et le gouvernement ecclésiastique. Or, les commentaires juridiques des canonistes comme Francesco Zabarella et Niccolò Tudeschi montrent que la participation populaire aux élections canoniques pouvait être tolérée sous certaines conditions. Selon cette étude, la méthode intellectuelle des canonistes, ainsi que certaines considérations pratiques, peuvent expliquer leur ouverture d'esprit vis-àvis de la participation lä̈que dans les élections canoniques. 
The general councils of the fifteenth century were situated on the threshold of a period of revolutionary change for the Church. The relationship between the people and the priesthood would be dramatically renegotiated in the course of the next two centuries. Secular parties would claim the right to superintend the clergy's duties and to regulate moral discipline within the Church. This was often accomplished against a background of violent agitation, or the threat of this. The leaders of the Church in the fifteenth century were themselves witness to a militant outburst of reforming energy in Bohemia, which sought to allow the community, among other things, the right to enjoy the Eucharist on equal terms with priests, to preach and to enforce Christian justice ${ }^{1}$. Against this background, the reforming work of the fifteenth-century councils may appear very feeble. The council fathers stand open to the charge that they made no attempt to harness the popular energy of the period to strengthen the Church. Even the conciliar theorists, who seemed to lay such weight upon the power of the Church as a community, were, in the eyes of one modern historian, fatally compromised by their nakedly hierocratic aims. The general councils were dominated by the higher clergy. As far as Walter Ullmann was concerned, "the lower clergy and educated laymen were, so to speak, knocking at the gate, and were refused entry." 2

Ullmann's claims have attracted comment from historians before. Francis Oakley has pointed out that Ullmann neglected those aspects of conciliarism which made provision for lay attendance. ${ }^{3}$ Johannes Helmrath also found Ullmann's claims questionable (albeit thought-provoking). ${ }^{4}$ Studies by Jürgen Miethke, Werner Krämer, Thomas Prügl and others, have given greater nuance to our

1. There were, of course, significant divisions of opinion within the Hussite movement about how far such reforms should go, and the agency through which they would be accomplished. Frantisek Šmahel, La Révolution Hussite: une anomalie historique, Paris, Presses universitaires de France, 1985, p. 74-83.

2. Walter Ullmann, A History of Political Thought: The Middle Ages, Harmondsworth, Penguin, 1965, p. 224.

3. Francis Oakley, "Figgis, Constance, and the Divines of Paris", American Historical Review, 75 (1969), p. 377-380.

4. Joseph Helmrath, Das Basler Konzil, 1431-1449: Forschungsstand und Probleme, Cologne, Böhlau, 1987, p. 92 and note 69 on the same page. 
understanding of conciliarist theories, and the place of laypeople within them ${ }^{5}$. This paper owes a huge debt to all these works. It wishes, however, to situate the thought of the council fathers in a context which may help to uncover the origins of their ambivalent attitudes towards laypeople. The clericalism of the councils has usually been analysed within the intellectual framework of conciliarism. But the conciliarist texts generally devoted little space to the status of ordinary lay people within the congregatio fidelium and laypeople occupied a marginal position in the reform agendas of the councils. I wish to account for this omission. I will take the works of ecclesiology as a staring point, but will attempt to view the council's aims in broader political and social perspective. It will be argued here that the battle against heresy had a decisive impact upon the councils' attitudes towards ordinary laypeople. In the debates with the Hussites, the council fathers' reservations about popular influence in the Church are most clearly exposed. Yet, if fear was the most salient motif in the council's dealing with the Hussites, there was also an awareness of the Church's reliance upon lay cooperation in daily administration. The uneasy balance between a regressive conservatism and a desire to stabilise layclerical relationships informs conciliar statements about popular participation.

The attitudes of the conciliar delegates towards the people were shaped by their practical experiences of Church government. The council fathers were not, of course, full-time polemicists. Many were beneficed, and so had some experience of quotidian Church government, even if, in many cases, their administrative duties were discharged vicariously. ${ }^{6}$ Many were trained in canon law. Their knowledge of the law, as an academic discipline and as a

5. Jürgen Miethke, "Die Konzilien als Forum der öffentlichen Meinung im 15. Jahrhundert", Deutsches Archiv für Enforschung des Mittelalters, 37 (1981), p. 740-741. Also see J. Miethke's forthcoming article, "Konziliarismus", Handwörterbuch zur Deutschen Rechtsgeschichte, ed. Albrecht Cordes and Heiner Lück, Berlin, E. Schmidt, 2004-. Werner Krämer, Konsens und Rezeption: Verfassungsprinzipien der Kirche im Basler Konziliarismus, Münster, Aschendorff, 1980; Thomas Prügl, Die Ekklesiologie Heinrich Kalteisens OP in der Auseinandersetzung mit dem Basler Konziliarismus, Paderborn, F. Schönigh, 1995.

6. On the difficulties of estimating the numbers and the careers of those present at the councils, see J. Miethke, "Konzilien als Forum der öffentlichen Meinung," p. 743-751; J. Helmrath, Basler Konzil, p. 71-83. 
set of practical guidelines, informed their attitudes towards power relations within the Church. Brian Tierney's formative work has shown that the laws regulating ecclesiastical corporations were fundamental to the development of conciliarism. ${ }^{7}$ This paper will excavate the substrata of assumptions which informed conciliarist views about lay participation in the Church. It will analyse the work of two prominent canonists at the councils: Francesco Zabarella and Niccolò Tudeschi (Panormitanus). Moving beyond their well-known statements concerning lay influence in the general councils, the paper will consider their treatment of popular participation in other ecclesiastical institutions and procedures. In order to narrow down this vast field the paper will focus on elections within the Church. As we will see, the same concepts informed the legal arrangements for episcopal elections as structured thinking about lay participation in conciliar decision-making. In conclusion, the paper will compare the theoretical prescriptions concerning popular influence in elections with the procedural realities in Western Europe. Although there was an increasing tendency in the later middle ages to reduce popular participation in ecclesiastical elections, there are several cases where it was countenanced. The problems involved in these negotiations reveal the ambiguities which would be seized upon in the Reformation era.

\section{THE CONCILIAR ENGAGEMENT WITH THE HERETICS}

Let us begin with the political and social context in which conciliar views towards popular participation in the Church were shaped. After the schism had been mended at Constance, the refutation of the Hussites was the most pressing item on the higher clergy's agenda. It initially gave the Council of Basel its raison d'être and its influence upon the representatives of the councils cannot be overstated. Yet it is strange that studies of the encounters with the Bohemians at Constance and Basel tend to isolate these experiences from the rest of the councils' activities. They have been treated (not without justice) as a botched job, which detracted

7. Brian Tierney, Foundations of the Conciliar Theory, Cambridge, Cambridge University Press, 1955. 
from the otherwise laudable reforming aims of the delegates. The engagement (or lack of engagement) with the Hussites at Constance and Basel has been thoroughly examined, yet arguably the extent of its impact upon the conciliar representatives has not been fully appreciated. ${ }^{8}$

The Hussite Revolution was an alarming prospect for prelates across Europe. It presented a clear challenge to the clerical monopoly of power within the Church. As such, it cast a shadow far beyond the territories immediately disturbed by the turmoil. England was, of course, intensely concerned by developments in Bohemia as it was accused of being the original breeding-ground of the Hussite heresy. ${ }^{9}$ The territories of the Holy Roman Empire were anxious about the commotions occurring on their doorstep. The University of Cologne felt impelled, for example, to take a leading role in the extirpation of heresy during this period, and sent the theologian Heymeric de Campo, among others, in a delegation to Basel, to aid it in its refutation of the Hussites. ${ }^{10}$ But French clerics, far beyond the immediate zone of conflict, were also alarmed. Their feelings of panic emerge in a clerical assembly held at Bourges in 1432, presided over by the Archbishop of Rouen, Amédée de Talaru. ${ }^{11}$ The assembly beseeched the French king to send delegates to the Council of Basel, even though the council had refused to obey Pope Eugenius's bull of dissolution. As well as being fitting, French attendance at Basel was necessary, owing

8. On the Bohemians' experience at Basel, see Frantisek Šmahel, Die Hussitische Revolution, vol. 3, ed. Alexander Patschovsky, Hannover, Hahnsche Buchhandlung, 2002, p. 1560-1591. For older, though still useful, studies, see: Ernest F. Jacob, "The Bohemians at the Council of Basel, 1433", Prague Essays, ed. Robert W. Seton-Watson, Oxford, Clarendon Press, 1949, p. 81-123. Paul de Vooght, "La confrontation des thèses hussites et romaines au concile de Bâle", Recherches de théologie ancienne et médiévale, 37 (1970), p. 97-137; p. 254-291.

9. Michael van Dussen, "Bohemia in English Religious Controversy before the Henrician Reformation", The Bohemian Reformation and Religious Practice, vol. 7, ed. Zdeněk V. David and David R. Holeton, Prague, Academy of the Sciences of the Czech Republic, 2009, p. 42-60.

10. Maarten J. F. M. Hoenen, "Academics and Intellectual Life in the Low Countries: The University Career of Heymeric de Campo", Recherches de théologie ancienne et médiévale, 61 (1994), p. 188-190; p. 197-202.

11. Histoire de l'Église depuis les origines jusqu'à nos jours, vol. 14: L'Église au temps du Grand Schisme et de la Crise Conciliare, 1378-1449, ed. Étienne Delaruelle, Edmond-René Labande and Paul Ourliac, Paris, Bloud \& Gay, 1962-1964, p. 234-235. 
to the danger of the Hussite rebels, whose leaders had spread their ideas among the Dauphiné, and incited popular riots in Forez and Mâcon. Ordinary people in these areas had been led to believe that their prelates were not their pastors, but were acting merely for financial gain. ${ }^{12}$ According to the assembly, the rebels in Forez and Mâcon held the conviction that worldly dominium (whether secular or ecclesiastical) was held only by those in grace, and that those who were in a state of mortal sin could not rule over their inferiors. Lords were to work the land as labourers, earning their bread through the sweat of their brow, and no taxes were owed to them. The rebels were also said to have declared that two priests were enough for their needs. ${ }^{13}$ These sentiments bear striking resemblance not only to the utterances of some of the Taborites but also to ideas espoused in the 1381 peasant uprising in England. ${ }^{14}$ Of course, it is entirely possible that the clergy were projecting their own fears onto the uprising. But even if the links between France and Bohemia were more imaginary than real, the assembly's testimony points to the grave concerns which heresy had aroused across Europe.

The debates over the Four Hussite Articles at the Council of Basel most clearly exposed the conciliar antipathy towards popular participation in ecclesiastical government. This reactionary trend is illustrated in the confrontation between Mikuláš of Pelhřimov and Gilles Charlier over the Hussite article which defended the right of the community to correct sins. ${ }^{15}$ Mikuláš of Pelhřimov was initially careful to distinguish between the various forms of correction-

12. Monumenta Conciliorum Generalium Seculi Decimi Quinti, vol. 2, Vienna, 1857-1935, p. 138: "mentes simplicium putarent ecclesie prelatos non pastorum, sed personas gerere mercanariorum".

13. Monumenta Conciliorum, vol. 2, p. 138: "ausique fuerunt dicere, quod in tota patria sufficerent duo sacerdotes, et quod omnes nobiles tenebantur ad labores manuum suarum ex divina sententia... ex hoc inferentes tributa dominis temporalibus solvi non debere". This error was said by the clerics to be "errori Bohemorum coniunctus".

14. Margaret Aston, "Lollardy and sedition, 1381-1431", Past and Present, 17 (1960), p. 1-44; M. Aston, "Corpus Christi and Corpus Regni: Heresy and the Peasants' Revolt", Past and Present, 143 (1994), p. 3-47. Rosamond Faith, "The "Great Rumour" of 1377 and Peasant Ideology", The English Rising of 1381, ed. Rodney H. Hilton and Trevor H. Aston, Cambridge, Cambridge University Press, 1984, p. 43-73.

15. Thomas A. Fudge, "Crime, Punishment and Pacifism in the Thought of Bishop Mikuláš of Pelhřimov, 1420-1452", The Bohemian Reformation and Religious Practice, ed. Zdeněk V. David and David R. Holeton, p. 69-103. 
ranging from physical coercion to fraternal correction-and the social orders to which these pertained. In general, the power of physical coercion belonged to secular princes, and the power of spiritual correction belonged to priests. Once this had been pointed out, he asserted that all members of the community, secular as well as spiritual, and of every rank, were obliged to correct those sinning against the law of God. Pelhrrimov was insistent that lay subjects could correct their clerical superiors in a spirit of charity, and to oppose their crimes publicly. ${ }^{16}$ Some of his arguments were drawn from orthodox teachings on fraternal correction, but in adjudging laypeople competent to decide whether priests had failed in their duties, he was in danger of infringing the teaching about the two swords, and the immunity of clerics from secular justice. ${ }^{17}$ Even more inflammatory was his assertion that peasants (rustici) could preach and write against the wickedness of priests, and his reminder that in the Old Testament they had even righteously slain priests. ${ }^{18}$ Even though he did not call for a rejection of the priesthood as a separate estate, Pelhřimov evidently wished to bring it within the ambit of communal justice, thus significantly reconfiguring layclerical relations.

In his rejection of Pelhřimov's arguments, the Council of Basel's spokesman, Gilles Charlier, emphasised the jurisdictional and moral superiority of the clergy. He argued this superiority meant that they could not be publicly admonished by their subjects for their sins or even for their faith, as such an action would lead to the retraction of the obedience owed to them. ${ }^{19}$ If correction were to occur, it

16. Orationes quibus Nicolaus de Pelhřimov, Taboritarum Episcopus, et Ulricus de Znojmo, orphanorum sacerdos, articulos de peccatis publicis puniendis et libertate verbi dei in concilio Basiliensi anno 1433 ineunte defenderunt, ed. F. M. Bartoš, Tabor, 1935, p. 14.

17. Orationes quibus Nicolaus de Pelhřimov, p. 15: "Item secundum leges ecclesie laycus debet accusare in casu clericum deliquentem et per consequens iudicare quod sit malus". For a study of the theory and practice of fraternal correction in late medieval England, see Edwin D. Craun, Ethics and power in medieval English reformist writing, Cambridge, Cambridge University Press, 2010.

18. Orationes quibus Nicolaus de Pelhřimov, p. 27: "Item prophete sancti, sacerdotes et rustici predicarunt et scripserunt contra cleri maliciam, ymo et clerum sub lege veteri meritorie occiderunt, ut patet de Helia propheta et Daniele et ceteris qui presbiteros occiderunt".

19. Sacrorum Conciliorum nova et amplissima Collectio..., vol. 29, ed. Gian D. Mansi, Venice, 1784-1785, p. 901. 
had to take place privately and with due reverence. Pelhřimov's advocacy of legal rigor in response to public sinfulness provokes telling comments from Charlier on the subject of the moral distinctions between the laity and clergy. In particular, he argued that prostitution should be tolerated by the Church authorities. This in itself was not particularly unusual: following Augustine and Thomas Aquinas, most authorities regarded prostitution as a necessary evil, which curbed sexual appetites and prevented them from overwhelming the social order. ${ }^{20}$ The traditional stress was on the pragmatic character of legal prohibitions. Charlier's use of the sources is noteworthy, however, for underscoring the moral gulf between the laity and the priesthood. He cited Aquinas to argue that the law could seek to prohibit only what could possibly be enforced. ${ }^{21}$ Seeing as most Christians fell considerably short of moral perfection, it was not feasible for the law to prescribe perfect sexual conduct. Charlier concluded that prostitution saved the polity from being disturbed, for it was not easy for the multitude to abstain from the pleasures and lusts to which they were addicted. ${ }^{22}$ The implication was that ordinary laypeople could not aspire to the same state of moral perfection as the priesthood, and this confirmed the laity's subordinate status in the administration of Christian justice.

The Council of Basel's rejection of the laity's right to discipline the clergy was only one aspect of its restrictive attitude towards lay involvement in the Church. It was implied that the detestable moral standards of the laity disqualified them from correctly discussing matters of the faith in public. ${ }^{23}$ The council also pointed out that the vernacularization of scripture was directly responsible for the proliferation of errors and heresies, since misguided readers could only grasp the husk of the words and not arrive at the root of their

20. James A. Brundage, "Prostitution in the Medieval Canon Law", Signs, 1 (1976), p. 825-845, esp. p. 830. Ruth M. Karras, "The Regulation of Brothels in Late Medieval England", Signs, 14 (1989), p. 399-433.

21. Aquinas, Summa Theologiae, IaIIae, q. 96 a. 2 and IIaIIae, q. 10 a. 11.

22. Sacrorum Conciliorum, vol. 29, p. 875. "Nam per ipsum non turbatur politia; nec plebium multitudinem lusibus, deliiciis et voluptatibus deditam facile est abstinere".

23. Concilium Basiliense, vol. 8, p. 79: "modernis, prochdolor, diebus quamplures laici, quos eciam de recta fide eorum detestabiles vita et mores parum commendant, de fide et eius articulis... publice et assuete disputant..." 
meaning. ${ }^{24}$ In a similar fashion, Jean Gerson argued that access to the vernacular scriptures encouraged erroneous interpretation, because the immediate, literal meaning of the biblical texts needed to be inserted within a matrix of scholarly interpretation in order to assume its true significance. ${ }^{25}$ Good character was identified as the bedrock of reliable scriptural interpretation. ${ }^{26}$ The exposition of biblical passages required men of outstanding intelligence, who were well-intentioned, humble in judgement, and immune from vice. In Gerson's view, doctors were to be ranked in accordance with their conformity to these attributes. ${ }^{27}$ Implicit here was the accusation that the heretics (and the lay estate in general) were not sufficiently endowed with clerical values to undertake the task of scriptural interpretation. These assumptions were also present in the work of Pierre d'Ailly. Preaching on the text from Luke 21, 25, "There will be signs in the sun, the moon and the stars", d'Ailly glossed the stars as references to the qualities required by the conciliar delegates. Even though no Catholic persons should be excluded from the assembly, the base and the ignorant were not specifically to be summoned. Instead, the conciliar representatives should excel in the three attributes of nobility: in their sublime eminence, in the clarity of their radiant wisdom and in the power of their influence. These conditions were most suitably fulfilled by those in charge of the administration of the Church: i.e. the clergy

24. Concilium Basiliense, vol. 8, p. 126: "solum enim corticem verborum et non radicem racionum sapiunt". See also Concilium Basiliense, vol. 8, p. 108.

25. Jean Gerson, De necessaria communione laicorum sub utraque specie, Oeuvres Complètes, ed. Palémon Glorieux, vol. 10, Paris, Desclée, 19601974, p. 57-58: "Scriptura Sacra dum per novellos homines inducitur tamquam credenda sit in suis nudis terminis absque alterius interpretis vel expositoris admissione, exponitur gravibus periculis et scandalis... ex hac praetera radice pestifera orti sunt et quotidie crescunt errores Begardorum et Pauperum de Lugduno, et omnium similium, quorum multi sunt laici habentes in suo vulgari translationem Bibliae".

26. The idea that reliable scriptural interpretation rested upon moral foundations can be found in Augustine. See Brian Stock, Augustine the Reader: Meditation, Self-Knowledge and the Ethics of Interpretation, Cambridge Mass., Harvard University Press, 1996, p. 174-242, esp. 198-199 and 228-232.

27. Jean Gerson, De necessaria communione laicorum, p. 57: "Comparandi sunt igitur doctores in expositione Sacrae Scripturae cum doctoribus, et illi quos constat habere conditiones positas in praecedenti regula [i.e. the one laying down the moral requirements for correct biblical exposition], praeferendi sunt non habentibus". 
(ecclesiastici) ${ }^{28}$ The same assumption of clerical superiority can be detected from a different perspective. When the opponents of the Council of Basel, such as Juan de Torquemada, wished to strike it a telling blow, they alleged that tavern keepers, domestic servants and other ignorant people were present in the assembly and held the same voting rights as the bishops and cardinals. ${ }^{29}$

These assertions of clerical pre-eminence in doctrinal matters can be linked to the broader struggle of medieval clerks to distinguish themselves from the unlearned. The disparagement which the university-trained élite heaped upon the uneducated has been illuminated by Alexander Murray. ${ }^{30}$ Klaus Schreiner has pointed out that medieval intellectuals, Gratian prominent among them, drew a sharp distinction between two types of Christian (duo genera Christianorum): the clerical estate with its competence over sacramental and theological functions, and the laity with its duties concerning earthly affairs, procreation, and the protection of the Church. This dichotomy had repercussions for the intellectual involvement of the laity in matters of faith, for they were often stigmatised as incapable of playing an equal role with clerics in the discussion of theology. ${ }^{31}$ The distinction was, of course, challenged in a university milieu, where philosophers championed their own secular version of the life of contemplation, replete with its own code of sexual morality. Alain de Libera has noted that Étienne Tempier's list of prohibited theses in 1277 sought, among other things, to besmirch the ideal of philosophical nobility with the stigma of sexual promiscuity in order that the theologians might recover the ideological monopoly of the celibate. ${ }^{32}$ Perhaps the

28. Pierre d'Ailly, Oratio... de officio imperatoris, papae, reliquorumque membrorum Concilii Constantiensis, Joannis Gersonii... Opera Omnia, vol. 2, ed. Ellies Du Pin, Antwerp, 1706, p. 921.

29. Sacrorum Conciliorum... Collectio, vol. 31, p. 65-66; p. 109. J. Helmrath, Basler Konzil, p. 83-84. These criticisms were repeated by others, such as Aeneas Silvius Piccolomini, Johannes de Palomar and Pietro del Monte. See also J. Miethke, "Konzilien als Forum der öffentlichen Meinung", p. 750.

30. Alexander Murray, Reason and Society in the Middle Ages [1978], Oxford, Clarendon Press, 1985, p. 237-244.

31. Klaus Schreiner, "Laienfrömmigkeit - Frömmigkeit von Eliten oder Frömmigkeit des Volkes?", Laienfrömmigkeit im späten Mittelalter, ed. Klaus Schreiner and Elisabeth Müller-Luckner, Munich, Oldenbourg, 1992, p. 1-78, esp. p. 13-26.

32. Alain de Libera, Penser au Moyen Âge, Paris, Seuil, 1991, p. 236. On the attempts of philosophers to raise themselves to a "quasi-priestly supremacy", see also A. Murray, Reason and Society, p. 265-270. 
accusation that the laity were innately sexual corrupt was used in a similar fashion by Gerson and Charlier. They were arguably widening the battlefield to encompass those outside the university walls who had challenged the clerical monopoly on learning, and the moral status that sustained it.

\section{THEORIES CONCERNING LAY PARTICIPATION AT THE COUNCILS}

The deep suspicions towards lay influence in the Church—salient in the councils' anti-heretical activities-can also be detected in the comments of the conciliarists about lay participation in the general councils. These theories have been thoroughly examined by a number of historians, so I will not analyse them here in great depth. They will instead provide a starting-point in a discussion about the ideological tensions which undercut the arguments that the laity should be entirely excluded from doctrinal debate.

The conciliar commentators who addressed the question of lay involvement, started from the premise that it was most appropriate for prelates and lesser clerics to attend the general councils. The scope for lay participation was nevertheless wider than may first appear. Gerson wrote that the council was a congregation drawn from every rank of the Catholic Church, and that no person who needed to be heard should be excluded. ${ }^{33}$ However, he made the distinction (which was accepted in practice at both Constance and Basel) between a consultative and a decisive voice. Only the latter had any force in the creation of conciliar decrees. In matters pertaining to the faith, the laity could cast no vote. In his proposals for universal participation, Gerson had in mind the exploitation of the particular competences of each rank in the Church hierarchy. If, for example, questions were raised about the repair of church buildings, stone-cutters and masons would be invited to the councils for their advice, and questions of philosophy and moral philosophy could be elucidated by lay people learned in these disciplines. ${ }^{34}$

33. J. Gerson, De Potestate Ecclesiastica, CEuvres Complètes, vol. 6, p. 240: "Concilium generale est congregatio... facta ad aliquem locum ex omni statu hierarchico totius Ecclesiae catholicae, nulla fideli persona quae audiri requirat exclusa".

34. J. Gerson, De Potestate Ecclesiastica, p. 241: "Si quaeratur de modo reparationis ecclesiarum materialium, esse potuerit in latomis vox consultiva; sic in 
Gerson's vision of the Church emphasised the compartmentalisation of practical and intellectual skills in a hierarchy of social functions. It should be noted, all the same, that he made large allowances for lay participation in the councils. Indeed, his proposals were far more inclusive than the regulations actually adopted at the councils, where lay representatives were almost exclusively the proctors of princes.

A similar open-mindedness towards lay participation is illustrated by the influential canonist Niccolò Tudeschi. ${ }^{35} \mathrm{He}$ was far less restrictive on this matter than his immediate predecessors. Of these, the famous fourteenth-century canonist Giovanni d'Andrea had set the tone. ${ }^{36}$ The Glossa Ordinaria of the Liber Extra put forward three occasions in which laypeople could be present at a general council. First, they could be invited to a council; second, they could be present when causes of the faith were being discussed; third, they could take part in the conciliar regulation of marriage, for when certain matters concerned them, they could be present. ${ }^{37}$ Giovanni d'Andrea strictly qualified the scope for attendance in these scenarios: laypeople were to be present to hear what was discussed. They were not to judge or teach on these matters. In fact, it was not even strictly necessary for the lay to be present at councils at all, because conciliar decisions could be made known to them by preaching. Sometimes they could attend in order to petition for justice, but when the councils handled clerical business or saw to the correction of priests, all laypeople had to be excluded.

Tudeschi, on the other hand, revealed more fully the ambiguity of the canonistic tradition on this matter, and clearly articulated his own disagreement with d'Andrea. First, he noticed that when matters of the faith had been discussed at the councils, laypeople

aurifabris et fabris; sic dum fit quaestio de philosophicis et moralibus disciplinis... possunt saeculares eruditi in philosophiae legibus et moribus dare consilium".

35. For a detailed assessment of Tudeschi's theories regarding lay participation, see Knut W. Nörr, Kirche und Konzil bei Nicolaus de Tudeschis, Cologne, Böhlau, 1964, 159-165.

36. It is, for example, repeated without demur by Francesco Zabarella in his commentary at x 3.10.10. All references are to Francisci Zabarellae super primo (-5) Decretalium libro... Commentaria, Florence, Thierry, 1602.

37. Glossa Ordinaria at X 3.10 .10 ad v. Contingere, Decretales Gregorii IX... suis comentariis illustratae, Paris, G. Merlin, 1561, col. 1198-1199. 
had occasionally intervened uninvited. ${ }^{38}$ On one hand, it was not necessary for laypeople to be called, because the power to decide matters of the faith had been given pre-eminently to clerics. Clerics, in effect, exercised power on the behalf of laypeople. Revealingly, Tudeschi cited anti-heretical laws, which prohibited laypeople from publicly or privately disputing the faith. ${ }^{39}$ Like other conciliarists, he was aware of the dangers of allowing lay people to discuss theological questions indiscriminately. However, if laypeople spontaneously presented themselves to the councils when the faith was being discussed, they were to be admitted. Tudeschi acknowledged that after the crucifixion of Christ, the faith had survived in only one lay woman: the Virgin Mary. The laity's claim to protect the faith could not, therefore, be dismissed entirely. In those cases where they presented themselves of their own accord, they were not confined to listening to the council's deliberations (as d'Andrea had claimed), but could give their advice and speak their mind. ${ }^{40}$

These assertions have been cited to demonstrate the openmindedness of the conciliarists towards lay participation..$^{41}$ The fact remains, however, that the theoretical allowances were not fully acted upon. At neither Constance nor Basel was there a sizeable lay party which availed itself of the opportunity to discuss matters of faith. Jürgen Miethke has shown that the councils were dominated by the clergy, with university graduates, in particular, overrepresented. ${ }^{42}$ The "democratizing" process at Basel was

38. N. Tudeschi, Concilia et Questiones, Turin, 1577, $\mathrm{n}^{\circ}$ 27, fol. 129r: "In causis autem fidei dicit quod laici intervenerunt etiam non vocati". See Glossa Ordinaria at D. 63 c. 2 ad v. Invitatur, Corpus Iuris Canonici... cum glossis diversorum, Paris, Nicolas Jullerion, 1618, col. 314.

39. For example, vi 5.2.2 in Corpus Iuris Canonici, vol. 2, ed. E. Friedberg, Lepzig, B. Tauchnitz, 1879, p. 1069-1070.

40. N. Tudeschi, Concilia et Questiones, fol. 129r: "sed si laici sponte se offerunt ad concilium in causa fidei: tunc puto quod debent admitti et sic proprie loquitur illud capitulum, ubinam [D. 96 c. 4] ibi enim imperator obtulit se. Et sic intelligo gloss. in c. adrianus. [D. 63 c. 2] cum enim fides potest remanere apud simplicem laicum ut dixi in aliis dubiis: quia non potest ecclesia esse nulla, interest cuiuslibet si vult interesse, ut admittatur et tunc puto quod non simpliciter audient, ut dicit Io. An. sed consulent et dicent opiniones eorum".

41. Francis Oakley, The Conciliarist Tradition: Constitutionalism in the Catholic Church 1300-1870, Oxford, Oxford University Press, 2003, p. 73, note 39.

42. J. Miethke, "Konzilien als Forum der öffentlichen Meinung", p. 751-753. 
reserved for the clergy, and after 1436 the incorporation of lay members in the council was almost entirely brought to an end. At most, laypeople accounted for less than one percent of the total number of incorporated representatives at any one time at Basel. Most of these were the ambassadors of secular rulers, and it is highly unlikely that there were any stone-masons among them. ${ }^{43}$ It is to this gulf between theory and practice that we must now turn.

\section{Popular influence in ECClesiastical ELECTIONS: THE CANONISTIC THEORY}

The fight against heresy hardened conciliar attitudes towards lay participation in the Church. Yet it did not generate any radically new ideas: its effect was instead to deepen pre-existing prejudices. The gap between theory and practice at the general councils was indicative of a broader ambivalence towards lay participation in ecclesiastical administration. It goes without saying that popular participation in the Church took many forms, and it is impossible to treat them all here. To narrow down this enormous field, I will concentrate upon ecclesiastical elections. ${ }^{44}$ This subject has been chosen because the laws concerning elections were of crucial importance in shaping the procedures of the councils themselves. In treating canonical elections, the canonists broached problems of representation and of trustworthiness, which pertained equally to conciliar decision-making. At first glance, lay participation in these processes would seem to be entirely ruled out by the later canon law. Yet under closer scrutiny, a more elaborate picture emerges.

The discussion must begin with the problems involved in identifying what is meant by the term populus in the sources. The word "people" is often used vaguely by historians, and even lawyers of the fifteenth century struggled to define populus exactly. By examining their definitions we can detect some of the legal commentators' assumptions about popular authority. The people assumed different guises in the pages of the canonists. On the one hand, they are envisioned as the mob, whose participation in

43. J. Helmrath, Basler Konzil, p. 84-85.

44. A masterful treatment of the subject can be found in R.H. Helmholz, The Spirit of the Classical Canon Law, Athens, University of Georgia Press, p. 33-60. 
decision-making is unwelcome and generally injurious. On the other, they are seen as a bulwark of the Church, whose humble assent is to be invoked by the clergy. These kinds of tensions can also be detected in élite attitudes towards lay devotion: Gerson felt it necessary to curb devotional practices which were out of keeping with official theology while at the same time sustaining the popular engagement with the faith. He admitted that the Church hierarchy occasionally had to make concessions to local practices, such as innovations in the worship of saints. ${ }^{45}$ The ambiguity of the lay-clerical divide was embedded in the use of the term populus. Francesco Zabarella concluded that in general, the terms populus and clericus were distinct. When the people were described in odious terms, then the clergy were not to be understood as included in their ranks. However in favourable cases the name "people" could include clerics. ${ }^{46}$ Even though they intended to reinforce the elevation of the clerical estate, the canonists could not help admitting that the clergy could at times be considered a part of the Christian people.

Indeed clericus was almost as vague a term as populus. Strictly speaking, it embraced the priesthood, but in was often applied to scholars or even literate people who had not been ordained. Very few of the authors examined in this paper were careful to define what they meant by clericus. My sense is that the canonists generally used the word to denote priests. In the case of the general councils, the references become murkier, and the apologists of the councils had good reason to conflate the two meanings of clericus. When a large number of university graduates were effectively taking control of the machinery of curial government (especially at Basel), it was very useful to blur the lines between university scholars and the priesthood. This kind of ambiguity could only strengthen the claims of the university-trained to represent the Church and to wield its jurisdictional and doctrinal powers.

45. See Daniel B. Hobbins, "Gerson on Lay Devotion", A Companion to Jean Gerson, ed. Brian P. McGuire, Leiden, Brill, 2006, p. 41-78. See Gerson's letter of 1412 to the Carthusians at Basel in Oeuvres Complètes, vol. 2, p. 151-152.

46. Zabarella ad Clem. 1.3.6: "In favorabilibus nomen populi comprehendit clerum". Edition consulted: Francisci Zabarellae... in Clementinarum volumen Commentaria, ed. P. Franchi, Venice, 1602. The clergy could also be included in the case of a general interdict on the populus: see Zabarella's gloss ad x 4.1.11. 
After this brief excursus, I wish to return to the canonists' theories on ecclesiastical elections, and the caveats which complicated the apparently clear-cut theory that the laity were to be excluded from these procedures. The locus classicus for the clericalist view was the decretal Massana (x, 1.6.56), which declared bluntly that if any laypeople were involved in the election of a prelate, the election would be void. ${ }^{47}$ This law was reinforced by the decretal Osius episcopus (x, 1.6.2), which dealt with an episcopal election in which the people were accused of interference. The Glossa Ordinaria drew the conclusion that no bishop was to be elected by popular acclamation, since the people were presumed to be acting in the hope of some kind of gain..$^{48}$ The gloss cited a saying from the Decretum: "the people are not to be followed, but taught," and one from the Codex: "the false voices of the people are not to be heeded." ${ }^{4}$

These cases seem to bear an obvious affinity to the disputed election of Pope Urban VI in 1387 (probably the most notorious clerical election of the fourteenth century). A few words should be said about this before I move on. Calling Urban's election into dispute, the dissenting cardinals claimed that the Roman crowd that had wished to see a Roman, or at least an Italian, elected to the papal throne, had threatened them with violence if they did not comply with their wishes. Such intimidation, the cardinals argued, had invalidated the election. ${ }^{50}$ The Camerary, Pierre de Cros, justified the cardinals' actions by declaring that Urban VI had occupied the papacy through the sedition and violent commotion of the people. ${ }^{51}$ This claim was to prove controversial, however. The

47. The rubric at $\mathrm{x} 1.6 .56$ states: "Non valet electio pontificis per laicos et canonicos facta, et si hoc habeat consuetudo, hoc dicit et quotidie solet allegari". See Decretales Gregorii IX, p. 226.

48. Gloss ad x.1.6.2, ad v. Populi: "Nota quod ad clamorem populi nullus est eligendus: quia spe aut gratia hoc faciunt, aut pretium inde recipiunt". See Decretales Gregorii IX, p. 121.

49. D. 62 c. 2 in Corpus Iuris Canonici, ed. Émil L. Richter and Émil Friedberg, Leipzig, B. Tauchnitz, 1879-1881, vol. 1, p. 234: "Docendus est populus, non sequendus". Cod. 9.47.12 in Corpus Iuris Civilis, ed. Paul Krueger, Berlin, Weidmann, 1954, vol. 2, p. 391: "Vanae voces populi non sunt audiendae".

50. Howard Kaminsky, Simon de Cramaud and the Great Schism, New Brunswick N. J., Rutgers University Press, 1983, p. 20-25; Walter Ullmann, The Origins of the Great Schism, London, Burns, Oates \& Washbourne, 1948, p. 69-89.

51. Daniel Williman, "The Camerary and the Schism", in Genèse et Débuts du Grand Schisme d'Occident, Paris, Éditions du Centre national de la recherche 
lawyers who leapt to Pope Urban's defence, among them Baldus de Ubaldis and Giovanni da Legnano, replied that the actions of the crowd could not be deemed to constitute true interference, in the sense of robbing the cardinal electors of their free will. Baldus argued that the cardinals' arguments would only hold true if they had been physically constrained by the crowd to give their consent. Of this, however, Baldus could see no evidence..$^{52}$ The arguments of Baldus and Legnano constituted a useful case for overlooking popular interference in canonical elections. It is striking that their claims are not mentioned in the texts of Zabarella and Tudeschi that will be analysed below, in spite of the fact that the latter canonists were almost certainly aware of the earlier jurists' opinions (indeed Zabarella had been a pupil of both Baldus and Giovanni da Legnano)..$^{53}$ The reasons are not far to seek. For one thing, the arguments of Baldus and Legnano ran against the grain of the canon law, which sought, on the whole, to stigmatize popular participation in clerical elections. Furthermore, the status of Urban's election continued to be disputed up until the Council Constance put an end to the Schism. Those of the Avignonese obedience refused to acknowledge the legitimacy of Urban and his successors until the bitter end. It would have been imprudent for Zabarella and Tudeschi to have introduced the extremely contentious example of Urban VI's election into commentaries which aimed to elicit the widest support among educated legal opinion.

Zabarella and Tudeschi passed over the claim that popular pressure was irrelevant to the outcome of a clerical election, so long as the electors retained their free will. Instead they chose to dwell on the inappropriate aspects of popular participation in canonical elections. It is noteworthy that Zabarella used classical authors

scientifique, 1980, p. 70: "Bartholomeus de Prinhano... sacrum papatum Romanum... per seditionem et popularem tumultum ac impressionem violenter occupaverit".

52. For Baldus's case, see Caesar Baronius, Annales Ecclesiastici, vol. 26, ed. Augustin Theiner, Bar-le-Duc, 1864-1883, p. 580-599, esp. p. 592-593. Legnano made use of the equally Hobbesian argument that even though the cardinals had not wished to elect an Italian, they had chosen Urban willingly in order to avoid death at the hands of the mob: Annales Ecclesiastici, vol. 26, p. 608. On Legnano, see Alexandra Gooden, "Papal authority and canon law in the fourteenth century: the writings of John of Legnano", Unpublished Oxford University DPhil dissertation, 2005. On the Urbanist legal case, see W. Ullmann, Origins, p. 143-169.

53. W. Ullmann, Origins, p. 145. 
and passages from the civil law (identified by some historians as the sources par excellence of medieval and early modern republicanism) to undermine the standing of the people in the decision-making process. Zabarella quoted Cicero's acerbic aside on Varus's seizure of the African government, where he questioned whether imperium was an appropriate term for something "which was offered to a private party by the agitation of the ignorant rabble, with no public consultation". ${ }^{44}$ Zabarella also cited Roman laws which declared that slaves manumitted through popular compulsion were not, in fact, free. ${ }^{55} \mathrm{He}$ was quick to link popular participation in ecclesiastical affairs with the mob rule deplored by his ancient authorities. The reference to manumission is particularly revealing, as there is no explicit indication in Osius episcopus that the electors had been intimidated by the crowds. Indeed, Tudeschi considered the possibility that the wrongfully elected bishop had adduced the approval of the people as a means of having his election confirmed by a superior. ${ }^{56}$

The distrust of the people continued to be evoked in the canonists' discussion of rules regarding the presumption of innocence and guilt. The words of Osius episcopus clearly accused the people of lacking good faith. Tudeschi declared that the wishes of the people as a whole were less reliable than the intentions of its more prudent members. There were many base persons among the people, who did not have correct judgement stemming from reason, and were therefore corruptible. Although certain laws stated that an accused individual should be presumed innocent, this presumption was not to be applied to all the individuals who constituted the people as a collective group. ${ }^{57} \mathrm{An}$ interesting comparison can be drawn between this conclusion and the assurance of the conciliarists that

54. F. Zabarella ad x 1.6.2. Cicero, Pro Ligario, 3: "si illud imperium esse potuit, quod ad privatum clamore multitudinis imperitae, nullo publico consilio deferebatur". See Cicero, Pro T. Annio Milone... ed. and trans. Nevile H. Watts, Cambridge, Mass., Loeb, 1931, p. 460-461.

55. Dig. 40.9.17. Cod. 7.11.3. See Corpus iuris civilis, vol. 1, p. 682-683 and vol. 2, p. 299.

56. N. Tudeschi ad $\mathrm{x} 1.6 .2$ in Commentaria... in Primum Decretalium Librum, Venice, 1592, fol. 105v: "Petebat iste confirmationem a superiore et de electione sua faciebat fidem ostendendo literas populi qui eum elegit".

57. N. Tudeschi ad x 1.6.2 in Commentaria, fol. 105r: "quilibet in singulari praesumitur bonus, ut in... [X 2.23.14]... et tamen in populo collecto non est ista praesumptio respectu singulorum, ut hic". 
the Church as a whole was blessed with unerring faith. This passage may be connected with the argument that lay people were more effectively represented by priests at the general councils than they would have been in person. As Johannes Helmrath has shown, the lay voice was understood to be subsumed within the clergy's at the Council of Basel..$^{58}$

Despite their depreciation of the people's integrity and their intellectual capacity, the canonists were practical men and they realised that the Church authorities could not turn an utterly blind eye to the wishes of the people. Another example from the Roman law was cited by Zabarella on the matter of popular interference in elections. The law from the Digest assigned the death penalty to those convicted of assassination. The death sentence was usually to be delivered only in consultation with the prince, but in some cases it might be safer for a judge to act immediately without consultation, if the mob could not be appeased in any other way. ${ }^{59}$ In an ecclesiastical context, Zabarella cited various situations in which the wishes of the people needed to be heeded: a man, barred from taking holy orders, might be admitted to the priesthood if this prevented dissension from tearing the community apart. ${ }^{60}$ Similarly, a bishop might resign his position, if his relationship with his flock was so acrimonious that it led to scandal. ${ }^{61}$

In the examples above, the wishes of the people are tolerated in order to preserve harmony within the community. Yet Tudeschi admitted that popular participation could be treated constructively and not simply as a nuisance which the Church was constrained to accept. Commenting on a decretal which mentioned the summoning of religious men (religiosi) to a collegiate election (the implication being that the men were not members of the college), Tudeschi cited various laws from the Decretum which adopted a more accommodating stance towards popular participation in

58. J. Helmrath, Basler Konzil, p. 90. This idea was prominent in the thought of Nicholas of Cusa. See Erich Meuthen, "Nikolaus von Kues und der Laie in der Kirche", Historisches Jahrbuch der Görres-Gesellschaft, 81 (1962), p. 105.

59. F. Zabarella ad x 1.6.2. See Dig. 48.8.16 in Corpus iuris civilis, vol. 1, p. 853.

60. D. 50 c. 25 in Corpus Iuris Canonici, ed. É. Friedberg, vol. 1, p. 187.

61. Glossa ordinaria ad x 1.9.10 ad v. Pro gravi: "Pro scandalo licitum est episcopo petere licentiam cedendi, cum aliter scandalum sedari non potest". See Decretales Gregorii IX, col. 257. 
ecclesiastical elections. One, a letter from Pope Gelasius, required two bishops to assemble all the laypeople (universam turbam) of a particular town in order to resolve a contested election. ${ }^{62}$ Tudeschi concluded that in these cases the people had not been called to take part in the election but to give their consent to the decision made by the electors..$^{63}$ This interpretation harmonised with the prescriptions regarding lay participation in the councils. In both cases it was expected that the people would play a largely passive role in the decision-making process. Yet the situation became more complex when Tudeschi considered a case in which the people decided to withhold their consent. Should the election made by the college be declared void? Tudeschi decided that it should not, if the people had contradicted the outcome with no good reason. It might be ruled otherwise, however, if a scandal were caused by ignoring the popular will. ${ }^{64}$ A gloss of the Decretum cited by Tudeschi went far further and stated that if a bishop had been elected without the consent of the people, then his consecration ought to be annulled, for the consent of the people was always required. ${ }^{65}$ Tudeschi cited two other laws which confirmed that legitimate canonical elections, which had selected the best candidate for the job, were to be declared void if a scandal to the people arose. ${ }^{66}$

It is immediately apparent that Tudeschi and Zabarella were not in the business of supplying one-dimensional answers to the questions raised in their commentaries. The twists and turns of their arguments should give us pause for consideration. It is puzzling that the later canonists did not seek to simplify the law,

62. D. 63 c. 11 in Corpus Iuris Canonici, ed. É. Friedberg, vol. 1, p. 238.

63. N. Tudeschi ad X 1.6.1 in Commentaria, fol. 104v: "Populus autem vocatur non ad eligendum, sed ad consentiendum electioni". Tudeschi cites D. 63 c. 27 in support.

64. N. Tudeschi ad x 1.6.1 in Commentaria, fol. 104v: "Sed adverte: pone quod populus non vult consentire electo per collegium, nunquid debet irritari electio? vide gl. not. 62 di. c. 1. q. dicit, quod non, ex quo non habet causam rationabilem contradicendi, nisi scandalum generetur".

65. Glossa ordinaria, ad D. 62 c. 1 ad v. Nec a plebibus: "Sed quod si aliquis est consecratus, qui non habuit consensum plebis, numquid cassabitur consecratio? Videtur quod sic, in odium consecrantium et eligentium, cum contemptus est... nam semper consensus plebis est requirendus." See Corpus Iuris Canonici, col. 312.

66. Glossa ordinaria, ad x 3.5.6 ad v. Si non potest: "Propter scandalum quandoque receditur a iure". Decretales Gregorii IX, col. 1120. See the gloss to X 1.9.10 cited above. 
separating out the chaotic accretion of conflicting judgements and providing a gloss which most nearly accorded with contemporary realities. They certainly had the theoretical tools with which to perform such an operation. It was recognised that changes in custom could invalidate old laws. Such principles of historical change were applied in theology, where they served to refute the demands of the heretics to return to the practices of the ecclesia primitiva. Nicholas of Cusa, writing to the Bohemians, declared that the rites of the sacraments had been variously performed over time, just as the scriptures had been variously adapted and understood. Christ had arranged that the mystery of the faith should hold true in a variety of circumstances. According to Cusa, the Hussites were not wrong in arguing that the Eucharist had been offered to the laity in both kinds in the primitive Church, but they were mistaken in believing that such an arrangement had been intended to be universally and eternally valid. ${ }^{67}$ Kantik Ghosh has shown that William Woodford used a similar historicising strategy in response to Wyclif's monologic brand of scriptural interpretation. ${ }^{68}$ These forms of multivalent scriptural hermeneutics had the aim, however, of reinforcing a single set of doctrines sanctioned by authority. If the scriptures were open to many readings, then an extra-scriptural adjudication of conflicting interpretations was required. The dialogic method of the canonistic commentaries had different results. It revealed the tensions within the legal tradition, often without decisively rejecting one or another of the available interpretations. Although they aimed to iron out the discrepancies of the law, the canonists often let them stand. Tudeschi could well see that decretals, such as Massana, which anathematized lay participation in elections, manifestly contradicted older determinations about the necessity of popular consent. There was no recognition in his glosses, however, that this conflict diminished the authority of the earlier law.

67. Nicholas of Cusa, Opera, Basel, 1565, p. 833: "diversis temporibus alius et alius ritus sacrificiorum et etiam sacramentorum stante veritate invenitur, scripturasque esse ad tempus adaptatas et varie intellectas... Christus enim... mysteria pro temporum varietate dispensat". On Nicholas's historical method, see W. Krämer, Konsens, p. 259-264.

68. Kantik Ghosh, The Wycliffite Heresy: Authority and the Interpretation of Texts, Cambridge, Cambridge University Press, 2002, p. 67-85. 
Purely intellectual reasons can be adduced for the canonistic method. ${ }^{69}$ The canonistic commentaries need to be related to modes of scholastic enquiry in other disciplines. Perhaps the dialectical methods of the canonists can be seen as a refuge for the scholastic method, at a time when they were coming under threat in many universities. At Oxford in the years after Wyclif's death, for example, many scholars took up the evangelical doctor's distrust of vain theological speculation and the uncertainties implicit in reconciling discordant traditions..$^{70}$ Of course, it was far from the intentions of the later canonists to replicate the philosophizing of the twelfth and thirteenth-century schools. But the enterprise of harmonising the entire corpus of the law necessitated its own forms of dialectical procedure, at a time when theologians were more insistently brandishing monologic interpretations of scriptural and patristic texts in their battles with the heretics.

The changes in ecclesiastical administration in the later Middle Ages also help to explain the canonists' grudging admissions concerning the acknowledgment of the popular will. As a large body of research has shown, the quotidian regulation of parish life could not have proceeded without the cooperation of the clergy and trustworthy lay members of local communities. In an English context, Ian Forrest has shown how lay support was enlisted by the clergy in the battle against Lollardy. The detection of heresy was dependent upon communal discernment and activism, and the secular government and the Church made extensive use of a system of public communication in order to mobilise popular involvement. ${ }^{71}$ But, needless to say, lay participation in the life of

69. A classic interpretation of the canonistic method may be found in Stephan G. Kuttner, "Harmony from Dissonance: An Interpretation of Medieval Canon Law", The History of Ideas and Doctrines of Canon Law in the Middle Ages, ed. S. G. Kuttner, London, Variorum, 1980, p. 1-16. Brian Tierney identifies the Decretum as "a running argument". See B. Tierney, Foundations of the Conciliar Theory, p. 25. What is lacking in both these accounts is an attempt to relate the canonistic method to other academic disciplines. On this subject, see Olga Weijers, Queritur utrum. Recherches sur la "disputatio" dans les universités médiévales, Turnhout, Brepols ("Studia artistarum", 20), 2009.

70. Jeremy I. Catto, "Theology after Wycliffism", The History of the University of Oxford, vol. 2: Late Medieval Oxford, ed. Jeremy I. Catto and Ralph Evans, Oxford, Clarendon Press, 1995, p. 264-265.

71. Ian Forrest, The Detection of Heresy in Late Medieval England, Oxford, Oxford University Press, 2005. 
the Church went far beyond the prosecution of heresy (and indeed far beyond anything mentioned so far in this paper), as prominent members of parish communities were entrusted with the handling of parish finances, the repair of the fabric of churches, and the arraignment and prosecution of public sinners before the Church courts, to name only a few examples. ${ }^{72}$ This participation was not accurately reflected in the canon law, ${ }^{73}$ but it is reasonable to assume that the canonists were aware of the practical arrangements made by the laity and the clergy at a local level, and recognised that in those rare cases where a local community was in persistent and damaging conflict with their priest or bishop, the cleric might be forced to stand down. This was to recognise a kind of negative election in ecclesiastical appointments - a popular veto in all but name.

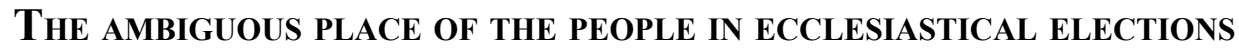

The conflicted theoretical description of the lay-clerical divide in the late medieval canon law was reflected in practice. In closing my discussion of the theories regarding lay participation in the Church, I would like to consider two examples of clerical elections in which popular involvement was mentioned. It goes without saying that the inferences drawn from these cases are not necessarily universally applicable. Nevertheless, within the frame of this paper, they are sufficient to suggest that ambiguities in the realm of theory were equally present in the practicalities of Church government.

It should, of course, be noted that many of the higher offices in the Church were no longer filled by canonical election in the fifteenth century. Bishops were increasingly chosen by papal reservation or the appointment of secular rulers. ${ }^{74}$ It appears to be

72. There were, of course, analogous forms of cooperation between local communities and central government within the realm of secular politics. See John L. Watts, "The Pressure of the Public on Later Medieval Politics", The Fifteenth Century IV: Political Culture in Late Medieval Britain, ed. Linda Clark and Christine Carpenter, Woodbridge, Boydell, 2004, p. 159-180.

73. Paul Ourliac, "L'Église et les laïques à la fin du Moyen Âge: étude de droit canonique", Études d'Histoire du Droit Médiéval, ed. P. Ourliac, Paris, A. et J. Picard, 1979, p. 607-620.

74. For changes in the laws and procedures governing episcopal elections in England, see R.H. Helmholz, The Oxford History of the Laws of England, Volume 1, Oxford, OUP, 2004, p. 491-4. 
the case, however, that in fifteenth-century France, after a period of abeyance, the rights of the cathedral chapter in episcopal elections were reasserted. Véronique Julerot has illustrated a remarkable competition between several rival candidates for the bishopric of Paris in $1492 . .^{75}$ She has revealed that some of these candidates used public processions and the posting of placards around the town as a means of enlisting popular support for their candidature, and for discrediting the candidature of others. Julerot finds in this election a striking demonstration of the quest for popular consent in the legitimisation of clerical elections. It is notable that in the subsequent judicial enquiry into the election, the canonical candidates themselves made attestations of the popular support that they had received. This remarkable solicitation of lay involvement demonstrates, at the very least, the recognition that the approval of the townspeople in Paris would be a useful asset to the future bishop.

In an English example, the ambiguities of clerical attitudes are more fully revealed. The case concerns a contested election to the deanery of Hereford in 1462. The election of a certain John ap Richard was originally reported to the bishop of Hereford, John Stanbury, as a model of canonical procedure. It is noteworthy that the letter of the chapter to the bishop, informing him of its decision, stressed the level of popular involvement in the election. A copious multitude was said to be present at the mass preceding the election. The letter was careful to stipulate, however, that the people had left the chapterhouse before the election itself had taken place. ${ }^{76}$ The chapter's scrupulous observance of canonical procedure was also reflected in its declaration that all absent canons were to be declared contumacious, in accordance with the constitution of the general council, Quia Propter, which was read out and shown to the canons by Richard Rudhale. ${ }^{77}$ The choice of Rudhale was surely

75. Véronique Julerot, "'Peuple' chrétien et élection épiscopale à la fin du $\mathrm{XV}^{\mathrm{e}}$ siècle", Revue d'Histoire de l'Église de France, 91 (2005), pp. 27-49.

76. Diocesis Herefordensis: Registrum R. Beauchamp... Registrum J. Standbury, ed. Arthur T. Bannister, London, Canterbury and York Society, 1919, p. 74: "omnibusque aliis tam clericis quam laicis in multitudine copiosa ibidem existentibus postea a dicta domo recedentibus et exclusis, convenientibusque tunc in ipsa domo capitulari omnibus canonicis subscriptis".

77. Diocesis Herefordensis, p. 76: "quibus sic peractis et constitucione concilii generalis, Quia propter, per magistrum Richardum Rudhale, archidiaconum 
not accidental, for he possessed a doctorate in canon law from the University of Padua, one of the most prominent law schools in Europe. Once the canons had reached consensus through a compromise solution, they were careful to publicise their decision in the vernacular to the assembled people, in accordance with the strictures of Quia propter about the avoidance of clandestine elections. ${ }^{78}$ The bishop himself evidently saw no apparent deficiencies in the election, because he confirmed it on 26 June 1462.

The chapter was not, however, as unified as it had pretended in its original letter, nor was the significance of the lay involvement uncontested. An appeal against the election of John ap Richard was launched, perhaps by those canons who had been absent at the election, perhaps by those involved in the dissensions preceding the compromise solution. Here the popular participation in the election was described in a very different manner from the original letter. The dissenting canons alleged that John Bayly would have been elected dean, had he not been hindered by the pressure of lay power, summoned by Richard Rudhale. It was only as a result of this lay obstruction that John ap Richard had been elected. ${ }^{79}$ It is now difficult to determine whether laypeople had really intimidated the electors, or whether certain factious canons had simply used this allegation as a pretext to force an episcopal annulment of the original election. What surfaces from the case, at all events, is the manifestation of the canonistic ambivalence towards popular involvement in a practical context. The multitude is portrayed in the original letter as a legitimate, passive but at the same time approbatory element in the election, which we have seen in the conciliar discussions of lay participation at the councils. In the letter of contestation, we are in the presence of the detestable mob described by Zabarella

antedictum, coram nobis ibidem ad tunc distincte et aperte perlecta et exposita". Quia propter was incorporated into the Liber extra at x 1.6.42.

78. Diocesis Herefordensis, p. 77: "nostram eleccionem et eius formam... clero et populo in magna multitudine ibidem congregatis mandavimus et fecimus in vulgari publicari”.

79. Diocesis Herefordensis, p. 81: "Johannes Bayly, vice sua et vice omnium canonicorum... in decanum eligisset, ni per impressionem potencie laicalis per dictum Ricardum Rudhale invocate horribiliter impeditus fuisset, et isto modo et non alio prefatus dominus ap Richarde per potenciam laicalem, ut premittitur, ductus fuerat ad summum altare..." 
in his commentary on Osius episcopus. Bishop Stanbury himself decided to interpret the intervention of laypeople with suspicion (perhaps favouring the maxim: dubia in deteriorem partem), for he invalidated the election of John ap Richard and annexed to himself the right of appointment to the deanery.

Both the Paris and Hereford election cases demonstrate that, in spite of the restrictions of the later canon law, popular approbation was sometimes considered a useful asset to canons competing for higher office. The Hereford election dispute shows the difficulties attendant on the use of popular participation as a tool of affirmation: it was open to contestation by those who viewed canonical elections as an exclusively clerical decision-making process. Nevertheless, the examples serve to remind us that the high clerical theory which disdained lay involvement in ecclesiastical decision-making was neither universally accepted nor immutably translated into practice. In parts of the Holy Roman Empire, in particular, it seems that lay parties had much greater influence over clerical elections than in the two cases mentioned here. ${ }^{80}$

\section{Conclusion}

At this point, we should return to consider the validity of Ullmann's critique of the councils. His comments certainly draw attention to significant omissions in the councils' reforming ideology. These need to be seen, however, not only in terms of an instinctive fear of the people, but as part of an extremely complex system of layclerical interactions. I have only been able to analyse one dimension of these relationships in this paper, but I hope nevertheless that my approach towards the councils has addressed some of the limitations of Ullmann's vision. I would argue that conciliar attitudes towards lay influence in the Church cannot be characterised purely as the result of unconscious oversight or prejudice, but as an unstable ideological compound, constantly tested by the countervailing

80. Dietrich Kurze, "Hoch- und spätmittelalterliche Wahlen im Niederkirchenbereich als Ausdruck von Rechten, Rechtsansprüchen und als Wege zur Konfliktlösung", Wahlen und Wählen in Mittelalter, Reinhard Schneider and Harald Zimmermann, Sigmaringen, Thorbecke, 1990, p. 197-225. 
pressures of an anti-heretical campaign and of the practicalities of ecclesiastical government.

The other problem with Ullmann's argument is that it is predicated upon a teleological reading of the period, where the democratizing forces of the Reformation sweep away the rotten hierarchical structures of the old Church. This reading is highly inaccurate. It is widely acknowledged among Reformation scholars that the fiery words of Luther and Zwingli about Christian liberty in 1520 quickly turned to fear and anger at popular extremism. ${ }^{81}$ Indeed, if there was a blurring of the lay-clerical divide among Protestants, there was also a concomitant accentuation of the divisions between those who possessed an education in the ancient languages and those who did not. ${ }^{82}$ Philipp Melanchthon stressed, for example, that the scriptures could only be adequately interpreted by those who had been thoroughly trained in the arts of grammar, logic and rhetoric ${ }^{83}$. This was designed quite explicitly to exclude the bulk of Christians from the theological debates superintended by the leaders of the Protestant churches ${ }^{84}$ In the Roman Catholic Church, too, the aims and assumptions of Trent were very close to those of the fifteenth-century councils. Even if the mood of activism was accentuated, it was still envisaged that the Church would be reformed primarily through the education of the clergy and the improvement of pastoral care. It was assumed that the laity would follow the clergy's lead. ${ }^{85}$ The

81. Robert W. Scribner, The German Reformation, London, Macmillan, 1986, p. 45; John S. Oyer, Lutheran Reformers against Anabaptists, The Hague, M. Nijhoff, 1964.

82. It has been noted that in Protestant churches, "possession of suitable learning set the minister apart... from the rest of humanity". Euan Cameron, The European Reformation, Oxford, Clarendon Press, 1991, p. 393.

83. Timothy J. Wengert, Human Freedom, Christian Righteousness: Philip Melanchton's Exegetical Dispute with Erasmus of Rotterdam, New York, Oxford University Press, 1998, p. 99-100.

84. For the view of German reformers towards learning and scriptural interpretation, see Erika Rummel, The Confessionalization of Humanism in Reformation Germany, Oxford, Oxford University Press, 2000, p. 39-48; R. W. Scribner, German Reformation, p. 50.

85. John W. O'Malley, Trent and all that: Renaming Catholicism in the Early Modern Era, Cambridge Mass., Harvard University Press, 2000, p. 131. Hubert Jedin replies to the criticism that Trent neglected laypeople by pointing out that this was outside the council's brief, i.e. to clarify the teachings of the Church. See H. Jedin, Crisis and the Closure of the Council of Trent: a retrospective view from 
fifteenth-century councils were not, therefore, the last gasp of an ideologically bankrupt Church. The ideological tensions that we have witnessed in this paper were part of a far longer process of negotiation and contestation over the value of lay involvement in ecclesiastical politics and matters of the faith.

Alexander.Russell@warwick.ac.uk

Centre for the Study of the Renaissance

University of Warwick

Coventry CV4 7AL

UK

the Second Vatican Council, trans. N. D. Smith, London, Sheed \& Ward, 1967, p. 162-163. 